\title{
Aprons Made from Canvas: The Legacies of Marie-Jacob Godefroid, Restauratrice to the French Royal Art Collections, 1741-1775
}

\author{
Yasemin Altun \\ College of Arts, University of Florida
}

Faculty mentor: Melissa Hyde, College of the Arts

\begin{abstract}
Eighteenth-century Paris was a site for significant changes in the art world, whether stylistically in the movement from Rococo towards Neoclassicism or socially in the growing presence of female artists. One field that emerged in this milieu was art restoration, here referring to the treatment of easel paintings in order to prevent signs of aging, such as surface discoloration, warping, etc. This paper focuses on MarieJacob Godefroid, a female art restorer active in the mid-eighteenth century whose career was unique in several regards, whether in life as a widowed mother or in work as an art restorer-dealer who received royal recognition. Launched from this biographic approach, my paper seeks to identify broader conceptions of womanhood that allowed female artists paths to success in a field hard-set by patriarchal traditions.
\end{abstract}

On the night of April 16, 1741, a group of friends from the Académie de Saint-Luc met for dinner in Paris at a restaurant on the Rue Saint-Thomas du Louvre, just in sight of the palace's eastern colonnade (Figure 1). It was a diverse cast of characters; among those present were a painter of battle scenes, a Belgian sculptor, and a Prussian engraver. Two other attendants included Jérôme-François Chantereau, a young painter to the King of Denmark, and JosephFerdinand Godefroid, a paintings restorer to the French Crown. These two had argued over dinner about the attribution of a work by the Italian painter Carlo Maratti. Godefroid also sold paintings from his restoration workshop on the neighboring Rue Saint-Germain-l'Auxerrois and had recently attempted to sell Maratti's The Flight into Egypt to James Waldegrave, the British Ambassador to Paris. The work's authenticity, however, remained suspicious to Chantereau, who likely rivaled Godefroid in serving a similar clientele of art collectors. As the two men were leaving the restaurant that night in 1741, their disagreement somehow became a duel, fought right in front of the Louvre's entrance gates. With swords drawn the older Godefroid was fatally 
stabbed in the ribs and died in a nearby church. The murder of Godefroid, whose role as a restorer and dealer made him an active figure in the Parisian art world was recorded in thorough detail by police, down to the number of coins found in his pocket. ${ }^{1}$

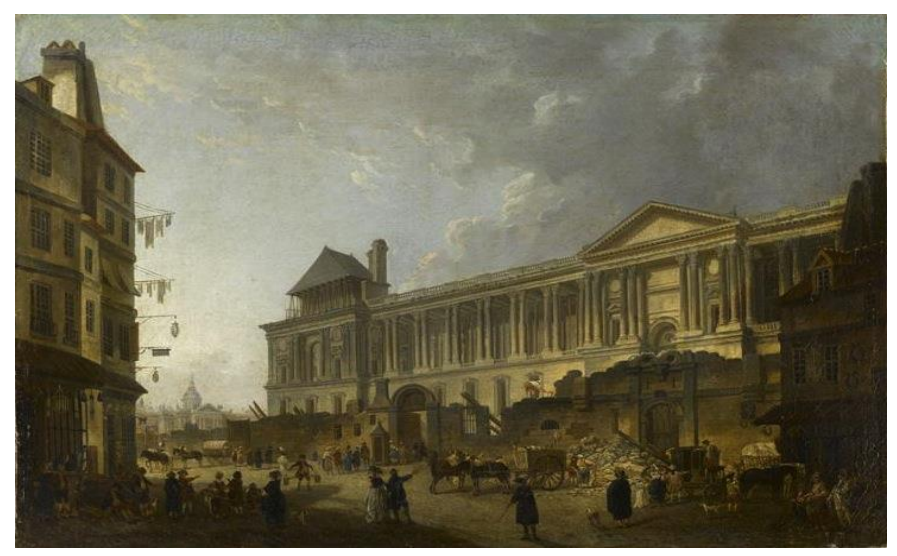

Figure 1. Pierre-Antoine Demachy, Vue de la colonnade du Louvre, 1772. Oil on canvas. Musée du Louvre, Paris. (RMNGrand Palais / Stéphane Maréchalle)

As shown by the fateful dinner's list of attendees, art circles in eighteenth-century Paris encompassed figures working in diverse fields. One person who did not attend the dinner, however, was the deceased's wife and business partner, Marie-Jacob Godefroid (1705-1775). Rather than witness the happy-hour gone wrong, she may have been managing the shop while her husband was out for the evening. The Godefroid couple had married circa 1726 and, by the late 1720s, had moved to Paris, where they ran a successful restoration business, receiving commissions from the Bâtiments du Roi and several private collectors. ${ }^{2}$

Marie-Jacob had worked as a restorer alongside her husband from the start of their marriage, but it was not until after his death that her career truly took off. Her professional freedom resulted in large part to the Ancien Régime legal system and specifically to its guild system, which granted widows rights unavailable to married women. ${ }^{3}$ As a member of the Académie de Saint-Luc since 1736, Marie-Jacob had inherited her husband's status as a master artisan and the property rights to their restoration business upon his unforeseen death in $1741 .^{4}$ Framing Marie-Jacob Godefroid's post-marital life (c. 1741-1775) as a career that reached new heights in the public sphere, this paper seeks to recast female widowhood as a status that could blossom rather than wilt. Building on the scholar Noémie Étienne's argument ${ }^{5}$ that Godefroid's 
business methods made restoration less an inventive secret and more an artisanal craft, this paper will argue that Godefroid's widow took advantage of Enlightenment conceptions of women as caretakers to reach a level of ambitious professionalism in the third-quarter of the eighteenth century.

From 1743 until her death in 1775, Marie-Jacob served as one of the Crown's exclusive restorers, treating masterpieces in diverse formats at the various royal residences in Paris and its vicinities. She performed mainly structural treatments, such as transferring paint layers from old wood panels onto fresh canvas, relining delicate canvas, and cradling wood panels. In addition to serving a pre-existing clientele from her husband's time, Marie-Jacob also built her own network that included figures of royal influence, such as the Marquis de Marigny and Charles-Nicolas Cochin. ${ }^{6}$ As a dual head of household and head of business, Marie-Jacob thus developed a highly specialized work identity as a marchande publique outside the traditional "family economy" and also received recognition for her work as a restauratrice. ${ }^{7}$

One prominent figure from the early-eighteenth century who praised the widow's diligence to her craft was the Parisian art dealer, Edme-François Gersaint. In his introduction to the 1748 joint-estate sales catalog of the banker Charles Godefroy and Marie-Jacob's husband, Joseph-Ferdinand, Gersaint states that the widow had worked as a restorer since at least 1720 and continued faithfully with this "daily occupation" after 1741 alongside another renowned Belgian restorer, François-Louis Colins. ${ }^{8}$ But once Colins died in 1760, Marie-Jacob appealed to the Bâtiments administration for the position of sole restorer to the royal paintings collection. ${ }^{9}$ After an epistolary deliberation between Cochin and Marigny, the former granted Godefroid her desired promotion, but she agreed to take on another restorer, Hugues-Henri Guillemard, to replace Colins in performing any surface treatments. ${ }^{10}$ Guillemard died only a few years later, at which point Godefroid's eldest son, Joseph-Ferdinand-François (1729-1788), began working alongside her until $1775 .{ }^{11}$ These many partnerships could indicate Godefroid's reliance on other male restorers, a view catering to the stereotype that widows were in physical and moral danger without a husband's authority. But upon further reflection, the widow's decades-long constancy equally highlights her evolution towards an independent career. Moving from dependence-inmarriage through multiple collaborations eventually to independence, Godefroid "climbed the restorer's ladder" as it was built. 


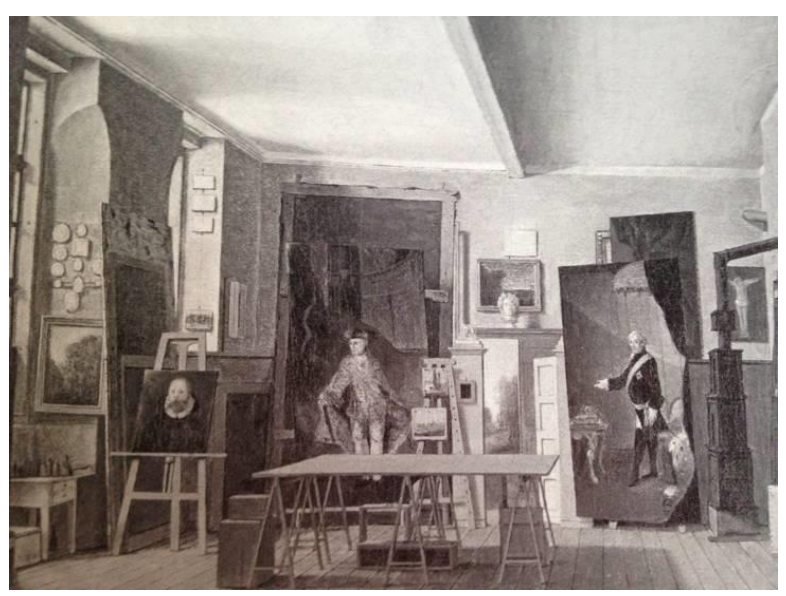

Figure 2. Berlin School, Interior of a Studio, c. 1830. Oil on canvas. Private Collection, Thuringia. (Massing, p. 103)

Although no portraits exist of Marie-Jacob Godefroid, contemporary images of studio, shop, and exhibition spaces can together give shape to her identity. Scenes of the restorer's studio are admittedly quite rare. A painting of a Berlin studio dated circa 1830 shows the workspace of a restorer of pictures, with his table of various solvents, dyes, resins, etc. arranged inconspicuously in the left-hand corner (Figure 2). The French artist Hubert Robert also painted romanticized scenes of such a space set in Rome (Figure 3) and in the Grand Gallery of the Louvre (Figure 4). Any lack of visual evidence dedicated to the restorer's workspace in the eighteenth-century is redeemed by specialized literature that abounded in the forms of artistic dictionaries, manuals, and even trade secrets. ${ }^{12}$ Many such writings from this period often discuss art production, sales circulation, and restoration in the same breath; indeed, one only needs to read La Font de Saint-Yenne's 1747 Salon critique or the Encyclopedia entry "Modern Painting" to know that restoration was a concern among artists, dealers, and theorists. ${ }^{13}$ One can then imagine that the art restorer's studio would have looked a lot like the artist's studio. 


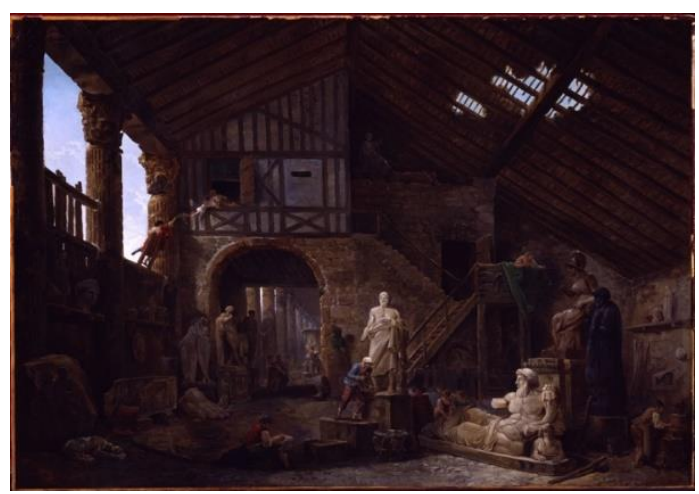

Figure 3. Hubert Robert, The Studio of an Antiquities Restorer in Rome, c. 1783. Oil on canvas. Toledo Museum of Art, Toledo, Ohio.

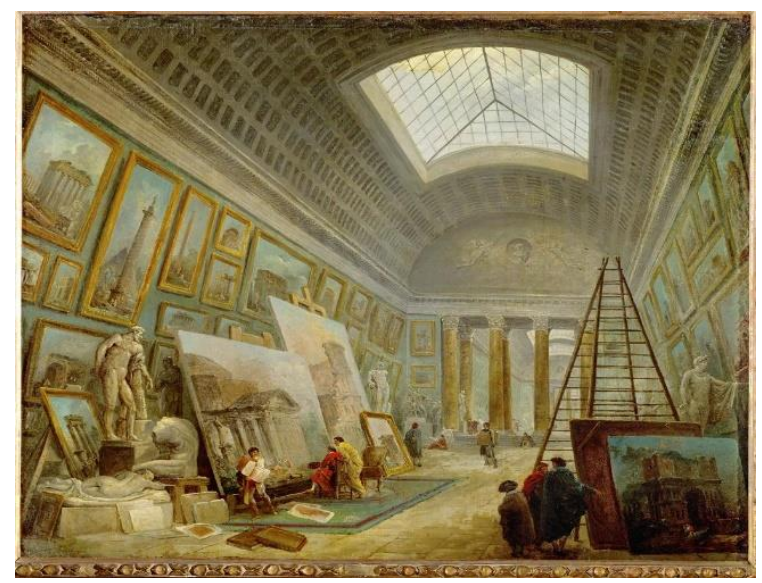

Figure 4. Hubert Robert, Museum Gallery, 1789. Oil on canvas. Louvre, Paris. (Erich Lessing/ART RESOURCE. N.Y.)

Marie-Jacob's career, working for the king while running an independent business, circled through royal and private spheres of activity. This dynamic is best illustrated by her two studio spaces.

The widow had lodgings at the Louvre palace, a tradition begun by Louis XIV of granting quarters to academies and distinguished individuals. By Marie-Jacob's time, however, the privilege had strained to accommodate an entire bustling community of artists and their entourages. Still, despite infamous accounts of their overcrowding and misuse, rooms in the Louvre remained prime real estate for artists seeking to network among their peers and clients. Indeed, for Godefroid it provided an opportunity to advertise her services to the most distinguished artistic circles in Paris. Throughout this time, however, she continued to work out 
of her hybrid shop-atelier on the Rue Saint-Germain-1'Auxerrois, just across the street from the palace. ${ }^{14}$ In contrast to the Louvre studios, a social space connected through extended families, Marie-Jacob's business location would have served as a kind of separate alcove-a room of her own - to which she could retreat at her own volition.

Another space integral to the Godefroid workplace was the dealer's shop. The atmosphere of the eighteenth-century commercial art scene is best shown in the sign painted by the Rococo artist Antoine Watteau for Gersaint in 1720 (Figure 5). Watteau's painting, although idealized, gives a sense of the types of actors on stage in the art world of its time. It was in fact split into two separate canvases early after the artist's completion, as attested by the seam that appears in reproductions. Multiple dualities exist across this lateral divide, such as those between old and new political regimes and the artistic styles they embody. But, there is also a clear allocation of labor between the manual work occurring to pack portraits on the left side and the transactional work occurring at the counter on the right. This distinction between front- and back-end shop duties refracts through the open door in the painting's very center, which presumably goes into a workroom that a restorer, such as Godefroid, would have occupied.

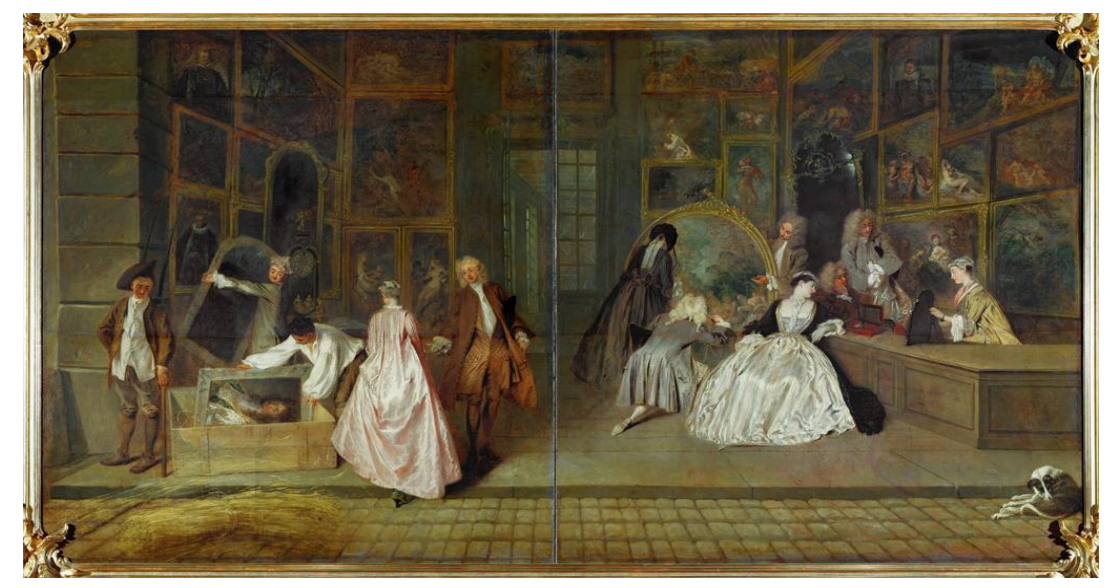

Figure 5. Jean-Antoine Watteau, The Shop-Sign of Gersaint (L'Enseigne de Gersaint), 1721. Oil on canvas. Schloss Charlottenburg, Berlin. (Erich

Gersaint's shop sign thus functions on two perpendicular planes: that showing the various activities of the visible shop front and that stretching between public and private shop spaces.

In view of Watteau's painting, this would mean stepping in from the street and walking straight through to the shop's back room. Put into other terms, the painted canvas has two perspectives. As a visual representation, it exists as regions on the surface-groups of figures each with their own role in the imagined workplace. As a physical object, however, Gersaint's 
shop sign exists as layers with actual depth; another front and back dynamic but played out within the material boundaries of the painting itself. Here the canvas's pictorial surface forms a kind of shop front just as the structural support forms its back room.

As noted already, Marie-Jacob Godefroid was a structural restorer. This meant that she prepared a painting for surface treatments by first performing any underside repairs. Étienne has insightfully noted that such a division of labor reflects a gendering of early restoration practice. ${ }^{15}$ While Godefroid executed many manual tasks, it was always her male partner who did the more painterly, iconographic treatments. In Revolutionary-era discourse, restorers would cite knowledge on schools of painting or Old Masters' stylistic signatures when distinguishing themselves from unskilled laborers. ${ }^{16}$ This dynamic mirrors broader conceptions of the female artist in the period, whose work was often considered imitative of or subordinate to a male teacher. Similarly, painters outside the royal Académie were often downgraded to an artisanal status. ${ }^{17}$ On the contrary, Marie-Jacob Godefroid inserted herself into some of the highest artistic circles of her time by embracing these traditional ideas of the female artist and artisan, and even the domestic model of womanhood made popular by Jean-Jacques Rousseau. By transforming her structural restoration work into a professional identity with a powerful backbone, MarieJacob maintained a long and varied career that left a legacy within her family and within the larger field of post-Revolutionary museum bureaucracy. Like the paintings she treated, Godefroid as a widow "restored" the legacy of her husband while generating a new one all her own.

A high point in Godefroid's career came in 1752, when she exhibited four paintings at the Salon of the Académie de Saint-Luc, held that May at the Paris Arsenal complex. ${ }^{18}$ These works belonged to Godefroid's private clients and had each been transferred from wood panel onto fresh canvas. It was her method for displaying the last painting by an unnamed student of Le Bourguignon that sparked the most interest. Godefroid sawed this panel in two, completed the transfer to canvas for half of the work, and left the other half on its original wooden support. In doing this, she enacted several layers of disruption. Firstly, she achieved recognition for her competence as a restorer using the newly popular transfer technique, thus ending the secrecy originally associated with it. ${ }^{19}$ But she also brought new dignity and visibility to a practice consisting of manual labor. The restorer's structural treatment here replaced the artist's rendering as the subject of display and brought new light to a "back-of-the-shop"-field of work. As the 
restorer's work in progress, this divided picture evoked a response from viewers because it showed a painting in the process of surgery. Foremost, by referencing the wooden panel on which the paint resides, Godefroid's treatment disrupted the entire illusion that an image claims to represent. No longer a window to another reality, the split panel became an object of physical cleavage - Godefroid perhaps only out-awed by the more famous widow beheading Holofernes.

Shortly after the 1752 showing, François-Bernard Lépicié, then secretary of the royal Académie, contacted Godefroid to inquire about her transfer technique. In the mid-eighteenth century, the transfer of panel paintings received extensive public interest and press coverage in Paris. The technique was initially associated in the 1740s with Robert Picault, who claimed to have invented a magical way of prolonging a painting's life by replacing its support structure. ${ }^{20}$ By 1752, however, Picault's non-disclosure drove a critique against the ridiculous prices he charged for routine work. ${ }^{21}$ Restorers, such as Godefroid, who advertised alternative methods and quoted lower costs, emerged as competitors. In 1753, when asked about the details of her transfer method, Godefroid confessed it was only a matter of "hot water and patience." Her frankness dissolved the illusion surrounding Picault's monopoly over the practice. As implied by Godefroid's “confession," her own transfer method was not magic, just ordinary work executed with great care. This specific method, similar to that used by other restorers through the earlynineteenth century, was as follows: she first would have shaved down the panel's wooden base until only a paper-thin layer remained. ${ }^{22}$ This layer contained the surface paint as well as priming layers in the ground. As promised, Godefroid would then have used warm water to soften and remove these preparatory layers and isolate the desired picture plane, which she could later glue onto a new canvas using a flour-based paste. Such use of everyday materials and mechanical processes had a broader impact on the restorer's status in the art world. Mid-century restorers, as embodied by Picault, had maintained a sense of charm and mystery that captivated public attention. But by the last quarter of the 1700s, after Godefroid's death, the restorer became a more anonymous and less favorable figure to the royal arts administration. ${ }^{23}$

In light of these developments, I would like to end my look at Godefroid by proposing a comparison between the position of the art restorer and that of the woman defined by French Enlightenment thinkers. As women transitioned from public influence in salons to more private roles in the home, the restorer moved from a figure for public entertainment to one for taking inventory. It is particularly Rousseau's brand of domestic womanhood, popular in the 1760s 
when Godefroid had established her reputation. This is not to suggest that the two cases are directly related, but that they represent two versions of the same limitation for women recorded in this period. Take in Book V of Émile, for example, where Rousseau lists a woman's duties as accorded by her sex. ${ }^{24}$ Here it is motherhood that defines the female life cycle, acting through innate qualities such as patience and gentleness. It is a woman's responsibility to maintain a balance within her household and bear healthy children for a prosperous, unified state. Art critics, such as La Font de Saint-Yenne, had used a similar language to describe the importance of maintaining royal art collections against the weathering of time. ${ }^{25}$ Like the diligent, nurturing mother, the restorer needed a sharp eye and gentle touch to care for such a rich assembly of art. And like Rousseau's enlightened housewife, the restorer required a specific, yet limited knowledge that perfected manual, practical tasks. Was Sophy, then, primed for a career in art restoration? If not, then what prevented her, and indeed all women apparently born with the necessary tools, from reaching this potential?

In her book on Elisabeth Vigée Lebrun, Mary Sheriff introduces exceptionalism as a term that both frees and limits the case of female artists in eighteenth-century France. ${ }^{26}$ Here the exceptional woman is someone who defies gender conventions to achieve unparalleled success. But as the exception, she cannot change tradition. The legacy of Marie-Jacob Godefroid presents a similar dilemma for singularity. On the one hand, Godefroid indirectly barred other female artisans from following in her footsteps after the arts administration minimized her influence. Equally possible, her humbling approach to restoration shifted down its qualifications, opening the field to more women. The careers of both women thus test gender as a variable for success. However, as a widowed art restorer who worked until her death and reached the highest level of an emergent field, Godefroid generates many exceptional variables. She was the exception to the exception. Of the relatively little known female artists in history, even less is known about female art restorers. Whether this is due to record or reality remains undetermined, yet Godefroid's career shows that sometimes it is possible to break the rules by following them.

\section{References}

Arbaud, Léon. "Mademoiselle Godefroid." Gazette des Beaux-Arts 11, no. 1 (1869): 38-52, 512-522.

Chatelus, Jean. Peindre à Paris au XVIIIe siècle. Nîmes: Éditions Jacqueline Chambon, 1990. 
Conti, Alessandro. A History of the Restoration and Conservation of Works of Art. Translated by Helen Glanville. Oxford: Elsevier, 2007.

Étienne, Noémie. "La Pensée dans la Pratique: Le Cas de Marie-Jacob Godefroid, Restauratrice de Tableaux au XVIIIe Siècle." In Plumes et Pinceaux: Discours de Femmes sur l'Art en Europe (1750-1850), edited by Mechthild Fend, Melissa Hyde and Anne Lafont, 77-97. Dijon; Paris: Presses du réel/INHA, 2012.

- The Restoration of Paintings in Paris, 1750-1815: Practice, Discourse, Materiality. Translated by Sharon Grevet. Los Angeles: The Getty Conservation Institute, 2017.

—. 'Un 'Ariste Connaisseur'? L'Expertise Du Restaurateur Dans l'Institution Muséale à La Fin Du XVIIIe Siècle.” Revue De Synthese 132, no. 1 (2011): 75-91.

Gersaint, Edme-François. Catalogue raisonné des tableaux, diamans, bagues de toute espéce, bijoux \& autres effets provenant de la succession de feu Monsieur Charles Godefroy, banquier \& joüaillier. Paris: Chez Pierre Prault, quay de Gêvres; Jacques Barrois, quay des Augustins, 1748.

Guiffrey, Jules Joseph, ed. "Histoire de l'Académie de Saint-Luc." In Archives de l'Art Français: Recueil de Documents Inédits Publiés par la Société de l'Histoire de l'Art Français. Vol. 9. Paris: Édouard Champion, 1915.

. "Joseph-Ferdinand Godefroy, Maître Peintre - Procès-Verbal et Information sur sa Mort Violente (1741)." In Nouvelles Archives de l'Art Français: Recueil de Documents Inédits, Publiés par la Société de l'Histoire de l'Art Français. Vol. 10. Paris: Charavay Frères, Libraires de la Société, 1883, 394-417.

Hafter, Daryl M. Women at Work in Preindustrial France. University Park, PA: The Pennsylvania State University, 2007.

Hafter, Daryl M. and Nina Kushner, eds. Women and Work in Eighteenth-Century France. Baton Rouge: Louisiana State University Press, 2015.

La Font de Saint-Yenne, Étienne. Réflexions sur quelques causes de l'état présent de la peinture en France. Avec un examen des principaux Ouvrages exposés au Louvre le mois d'Août 1746. Paris: À La Haye, Chez Jean Neaulme, 1747.

Lanza, Janine Marie. From Wives to Widows in Early Modern Paris: Gender, Economy, and Law. Aldershot, England; Burlington, VT: Ashgate, 2007.

Marandet, François. "The Banker Charles Godefroy and His Dealings in Paintings, or the Secrets of an Account Book Revealed (1738-48)." The Burlington Magazine 150, no. 1265 (Aug. 2008): 521528.

Marot, Pierre. "À propos d'un tableau du Musée historique lorrain: Recherches sur les origines de la transposition de la peinture en France." Annales de l'Est 5, no. 4 (1950): 241-283.

Massing, Ann. Painting Restoration Before La Restauration: The Origins of the Profession in France. London: Cambridge: Harvey Miller; Hamilton Kerr Institute, University of Cambridge, 2012. 
Sheriff, Mary D. The Exceptional Woman: Elisabeth Vigée-Lebrun and the Cultural Politics of Art. Chicago and London: The University of Chicago Press, 1996.

\section{Endnotes}

${ }^{1}$ For a full description of the 1741 murder see Jules-Joseph Guiffrey, ed., "Joseph-Ferdinand Godefroy, Maître Peintre - Procès-Verbal et Information sur sa Mort Violente (1741)," in Nouvelles Archives de l'Art Français, v. 10 (Paris: Charavay Frères, 1883), 394-417.

${ }^{2}$ Noémie Étienne, The Restoration of Paintings in Paris, 1750-1815: Practice, Discourse, Materiality, trans. Sharon Grevet (Los Angeles: The Getty Conservation Institute, 2017), 19-20; François Marandet, "The Banker Charles Godefroy and His Dealings in Paintings, or the Secrets of an Account Book Revealed (1738-48)," The Burlington Magazine 150, no. 1265 (Aug., 2008): 522; Marot, “À propos d'un tableau du Musée historique lorrain," 255.

${ }^{3}$ Janine M. Lanza, From Wives to Widows in Early Modern Paris (Aldershot, England; Burlington, VT: Ashgate, 2007), 8-12, 222-224.

${ }^{4}$ Noémie Étienne, "La Pensée dans la Pratique: Le Cas de Marie-Jacob Godefroid, Restauratrice de Tableaux au XVIIIe Siècle," in Plumes et Pinceaux: Discours de Femmes sur l'Art en Europe (1750-1850), eds. Mechthild Fend, Melissa Hyde and Anne Lafont (Dijon; Paris: Presses du réel/INHA, 2012), 81.

${ }^{5}$ Étienne, The Restoration of Paintings in Paris, 1750-1815, 29-48.

${ }^{6}$ Ibid., 66-72.

${ }^{7}$ Daryl M. Hafter, Women at Work in Preindustrial France (University Park, PA: The Pennsylvania State University Press, 2007), 11-12, 74-87, 178, 239-242; Lanza, From Wives to Widows in Early Modern Paris, 10, 121-122; Nancy Locklin, "Women and Work Identity," in Women and Work in Eighteenth-Century France, eds. Daryl M. Hafter and Nina Kushner (Baton Rouge: Louisiana State University Press, 2015), 33-51.

${ }^{8}$ Edme-François Gersaint, Catalogue raisonné des tableaux provenant de la succession de feu M. Charles Godefroy, banquier et joaillier (Paris: Chez Pierre Prault, quay de Gêvres: Jacques Barrois, quay des Augustins, 1748), vi-vii.

${ }^{9}$ Chatelus, Peindre à Paris au XVIIIe siècle (Nîmes: Éditions Jacqueline Chambon, 1990), 200-201.

${ }^{10}$ Massing, Painting Restoration Before La Restauration, 72, 86n96 (see also Appendix 3.2, p. 267).

${ }^{11}$ For a brief biography on J.-F.-F., see Léon Arbaud, "Mademoiselle Godefroid," Gazette des BeauxArts 11, no. 1 (1869): 39-43.

${ }^{12}$ Ann Massing, "From Books of Secrets to Encyclopedias: Painting Techniques in France between 1600 and 1800," in Historical Painting Techniques, Materials, and Studio Practice: Preprints of a Symposium, University of Leiden, the Netherlands, 26-29 June, 1995, ed. Arie Wallert, Erma Hermens, and Marja Peek (Marina Del Rey, CA: Getty Conservation Institute, 1995), 20-29; Massing, "Painting Materials and Techniques: Towards a Bibliography of the French Literature Before 1800," Die Kunst und ihre Erhaltung. Rolf E. Straub zum 70. Geburtstag gewidmet, Wernersche Verlagsgesellschaft (Worms 1990), 57-96. 
${ }^{13}$ Étienne La Font de Saint-Yenne, Réflexions sur quelques causes de l'état présent de la peinture en France. Avec un examen des rincipaux ouvrages exposés au Louvre le mois d'août 1746 (Paris: La Haye, 1747), 28-41, 64-67; Louis, le Chevalier de Jaucourt, "Modern Painting," The Encyclopedia of Diderot \& d'Alembert Collaborative Translation Project, trans. Aida Audeh (Ann Arbor: Michigan Publishing, University of Michigan Library, 2006). Originally published as "Peinture Moderne," Encyclopédie ou Dictionnaire Raisonné des Sciences, des Arts et des Métiers, 12: 275-277 (Paris, 1765).

14 Étienne, The Restoration of Paintings in Paris, 17; Massing, Painting Restoration Before La Restauration, 79-83.

${ }^{15}$ Étienne, "La Pensée dans la Pratique," 80-81.

${ }^{16}$ Étienne, “Un ‘Ariste Connaisseur'?” 78-83.

${ }^{17}$ Étienne, The Restoration of Paintings in Paris, 35-36; Guichard, “Arts Libéraux et Arts Libres à Paris au XVIII Siècle," 54-56.

${ }^{18}$ Guiffrey, Histoire de l'Académie de Saint-Luc, p. 33 and Livrets des Expositions de l'Académie de Saint-Luc à Paris, p. v-x, 19, 41.

${ }^{19}$ Étienne, The Restoration of Paintings in Paris, 184-185.

20 Alessandro Conti, A History of the Restoration and Conservation of Works of Art, trans. Helen Glanville (Oxford: Elsevier, 2007), 138-143; Étienne, The Restoration of Paintings in Paris, 30-33.

${ }^{21}$ Conti, A History of the Restoration and Conservation of Works of Art, 151-157.

${ }^{22}$ Massing, Painting Restoration Before la Restauration, 42-44, 179-180.

${ }^{23}$ Étienne, The Restoration of Paintings in Paris, 33-43.

${ }^{24}$ Jean-Jacques Rousseau, Émile, trans. Barbara Foxley (London; New York: Everyman's Library, 1972), 324.

${ }^{25}$ La Font de Saint-Yenne, Réflexions sur quelques causes de l'état présent de la peinture en France, 41.

${ }^{26}$ Mary D. Sheriff, The Exceptional Woman: Elisabeth Vigée-Lebrun and the Cultural Politics of Art (Chicago and London: The University of Chicago Press, 1996), 1-3. 